\title{
On Types of Correctional Institutions
}

\author{
SERGEI M. SAVUSHKIN \\ Tomsk Institute of Advanced Training of Employees of the Federal Penal Service \\ of Russia, Tomsk, Russian Federation \\ ORCID: https://orcid.org/0000-0002-5744-8178, e-mail: savusertom@rambler.ru
}

\begin{abstract}
Introduction. Due to the different density of population in the Russian Federation and the scale of its territory, correctional system facilities should represent a unified system, in which the institutions are interrelated and interchangeable. In the conditions of a large number of types and sub-types of correctional institutions, the possibility of interchangeability is weakened. Problems associated with the quality of ensuring the internal isolation of convicts have a significant impact on the level of crime and penitentiary security. Hence, the punishment execution practice should more flexibly use the norms on separation of convicts to achieve goals and objectives of the penal executive legislation. Methods: the research used a dialectical method for cognizing objective reality, a logical method, a modeling method, a formal legal method, a systemic method. Results and discussion: the constantly changing socio-criminological portrait of the offender and the level of crime force the legislator to revise criminal-legal and criminal-executive criteria for differentiating those sentenced to imprisonment. The mentioned reasons also affect group differentiation that occurs in the process of distributing convicts to dormitory accommodation (cells) within the correctional institution. The crime level in a separate RF subject and changes in the state criminal policy require the reassignment of correctional institutions as a whole. The system of correctional institutions should not overwhelmingly depend on the criminal-legal criteria of those sentenced to imprisonment and the changing criminal policy of the state, and at the same time, departmental regulation should not bolster the legislatively established system of correctional institutions. Conclusions: the legislator has established a wide range of types of correctional institutions for those sentenced to imprisonment. Remoteness of some of them from the place of residence of convicts, to a certain extent, has both positive and negative impact on their social ties, which ultimately affects the effectiveness of implementation of the panel enforcement legislation goals and objectives.

Keywords: panel enforcement legislation; types of correctional institutions; deprivation of liberty; subject of panel enforcement law; imperative legal regulation method; principle of differentiation and individualization of sentence enforcement; differentiation of those sentenced to imprisonment; separation of convicts; prison; panel settlement; correctional camp (colony).
\end{abstract}

12.00.08 - Criminal law and criminology; panel enforcement law.

For citation: Savushkin S.M. On types of correctional institutions. Penitentiary Science, 2021, vol. 15, no. 4(56), pp. 860-867. DOI 10.46741/2686-9764-2021-15-4-860-867.

\section{Introduction}

The constantly changing socio-criminological portrait of the offender and the level of crime are forcing the legislator to revise various criteria for classification of those sentenced to imprisonment in order to ensure the implementation of criminal and panel enforcement legislation goals. What is more, certain provisions of international acts on punishment execution are focused on classifying convicts in order to pre- vent malign influence of negatively characterized offenders, as well as facilitate their treatment with a view to their social rehabilitation (Rule 93 of the Nelson Mandela Rules).

So, international standards define the necessity to consider the level of danger of prisoners and, at the same time, authorize holding all categories in one correctional institution, provided that some of them are kept separately. Even the 1915 General Prison Instruction of Russia stipu- 
lated that prisoners who had a bad influence on others were "placed mainly in solitary cells at night separation".

So, for example, unlike the PEC of the Russian Federation, the 1970 RSFSR Corrective Labor Code (as amended December 18, 1970) identified three types of correctional labor institutions: correctional labor colonies, prisons and educational labor colonies (Article 12). With regard to their sub-types, there were 12 institutions: 3 types of panel settlements (Article 18 ), educational labor colonies with a child care home (Article 18), colonies of general regime, intensive regime, strict regime, special regime (Article 61), educational labor colonies of general and reinforced regime (Article 74). This system also included detention centers (Article 16) in terms of keeping convicts for economic services.

Further this legislative gradation of institutions only expanded. The system of correctional institutions as amended by the RSFSR Corrective Labor Code as of May 25, 1989 was supplemented by a correctional labor colony designed for maintenance and treatment of the convicts having infectious disease. V.A. Fefelov notes that correctional labor legislation and directive acts provided for more than 50 varieties of institutions that perform deprivation of liberty [11, p. 8].

Nowadays, in accordance with Article 56 of the Criminal Code of the Russian Federation, deprivation of liberty means isolation of a convicted person from society by sending him/her to a panel settlement, a juvenile correctional facility, a medical correctional facility, a correctional camp of general, strict or special regime, or to prison.

A slightly different classification of correctional institution types is provided by Part 1 of Article 74 of the RF Panel Enforcement Code. It comprises correctional camps, juvenile correctional facilities, prisons, medical correctional facilities, as well as pre-trial detention centers in cases stipulated by law (Article 77 of the RF PEC). The panel enforcement classification provides for 4 types of correctional camps: a panel settlement, correctional colonies of general, strict and special regimes. As the analysis of the current legislation shows, each type has a corresponding sub-type (for example, a correctional colony for those sentenced to imprisonment for the first time, for those who have been previously sentenced to imprisonment, for former employees of courts and law enforcement agencies).
It should be noted that when determining these sub-types of correctional institutions, it is reasonable to consider not only the legislation itself, but also law enforcement acts, with the order of the Director of the Federal Penitentiary Service of Russia dated February 12, 2010 being one of them. It stipulates that, according to Article 80 of the RF Panel Enforcement Code, separation of certain categories of convicts should be strictly guided by the requirements of the said article, namely: the persons sentenced to imprisonment for the first time should be kept separately from the convicts who have previously served imprisonment, regardless of conviction expungement or cancellation of a criminal record. To date, if there is only one correctional camp in a RF subject (for example, a general regime colony for convicts serving their first sentences), a convicted person, regardless of the fact of serving a sentence earlier, can be held to serve his/her sentence in this institution, since Article 80 of the PEC of the Russian Federation is applied differently in many subjects. So, in practice, there is a wide range of correctional institution types, which should be discussed in more detail.

\section{Methods}

The dialectical method of objective reality cognition is used in the research. So, the analysis of correctional institutions is carried out in conjunction with other subjects of panel enforcement relations.

The content of the government institutions system in the previously existing legislation is studied with the help of the logical method. Specific ways of improving panel enforcement relations are determined on the basis of the modeling method. The formal legal method is used in the study of normative legal documents.

Results

\section{Correctional camps}

To date, correctional colonies are represented by an expanded system of institutions (684 facilities). They hold more than $93 \%$ of those sentenced to imprisonment (including those sentenced to life imprisonment). The legislation identifies several types of colonies, depending on the regime:

1. Correctional colonies of general regime. To date, 7 types of correctional colonies of general regime can be distinguished: for men convicted for the first time; for men who have previously served their sentences; for women convicted for the first time; for women who have previously served their sentences; for men from among former employees of courts 
and law enforcement agencies; for women from among former employees of courts and law enforcement agencies; correctional colonies with a child care home.

Pregnant women, nursing mothers and women (including minors) with children are kept in correctional colonies with child care homes, together with female convicts from among former employees of courts and law enforcement agencies. Scientific works of foreign scientists note that correctional institutions for convicted women do not always take into account gender characteristics, their physiological needs, etc. [14].

It seems that in the light of expansion of the dispositive principles of panel enforcement regulation in the future, it is possible to discuss the necessity of creating correctional institutions with child care homes for men with children under the age of three who are the only parent (by analogy with convicted women).

Former employees of courts and law enforcement agencies who have previously served their sentences and those convicted for the first time are kept in the same correctional colonies, but separately from each other, like all other categories of convicts, provided for by law until 2010.

The Law of the Russian Federation No. 54731 "On institutions and bodies executing criminal punishment in the form of imprisonment", as of July 21, 1993 in Article 6, identifies correctional institutions with special conditions of economic activity, such as harvesting, processing of wood and other forest resources. We do not consider them to be an independent type or sub-type, since their differences actually consist only in production activities.

2. Correctional colonies of strict regime. Based on the analysis of the panel enforcement legislation, we can identify 3 sub-types: colonies for men convicted for the first time; for men who have previously served their sentences; for men from among former employees of courts and law enforcement agencies. As in general regime colonies, former employees of courts and law enforcement agencies, convicted for the first time and those who have already served a sentence of imprisonment, are kept in the same institution, but separately from each other, which indicates that the requirement of separate keeping of convicts without a special status is controversial.

3. Correctional colonies of special regime. There are the following institutions: for men convicted of especially dangerous recidivism; for men sentenced to life imprisonment, and persons for whom the death penalty has been replaced by imprisonment by pardon; for men from among former employees of courts and law enforcement agencies.

It is critical that former employees of courts and law enforcement agencies sentenced to life imprisonment are kept on general terms, but isolated from other convicts. There is also no special regime correctional colony for men sentenced to life imprisonment or for whom the death penalty has been replaced by imprisonment by pardon.

\section{Panel settlements}

Panel settlements have the following subtypes: for those who have committed a crime out of negligence, those who have not previously served their imprisonment and those convicted for the first time for committing intentional crimes of little or medium gravity; for those convicted of crimes committed out of negligence, and those who have previously served imprisonment and convicts, positively characterized, who have been transferred from general and strict regime colonies; for convicts from among the former employees of courts and law enforcement agencies, which keep all the categories of convicts listed above with a special status (therefore, in our opinion, we can say that this type of institution is an independent (third) type of a panel settlement.

According to V.D. Ivanov, since convicts kept in a panel settlement are not actually deprived of liberty, but are restricted in it, it is advisable to remove this type of institution from Articles 56, 58 of the RF Criminal Code and Article 74 of the RF Panel Enforcement Code, as it does not meet the requirements of isolation from society [2, p. 24]. This proposal is rather controversial, since there are currently no legally defined requirements to ensure isolation. In addition, it seems that the communication of convicts with the outside world is not considered as punishment, but enhances their social rehabilitation.

Domestic and foreign scientists note that the level of isolation of correctional institutions affects the degree of negative impact of penitentiary environment. The reduction in isolation restrictions contributes to the strengthening of socially useful ties of a convict. In our opinion, these facilities are a mandatory element of the panel institutions system, which include open, closed and prison-type institutions [10, p. 103]. Juvenile correctional facilities

The analysis in the criminal cycle branches allows us to conclude that the convicts who have 
not reached the age of 18 (in exceptional cases - 19) are kept in juvenile correctional facilities. As of January 1, 2021, 949 convicts served their sentences in 18 juvenile correctional facilities (with a limit of 4,919 people), of which 68 were female. On average, 45 offenders account for one educational colony. Moreover, unlike correctional colonies, there is no large gradation of sub-types, since there are juvenile correctional facilities only for male and female convicts.

Earlier, Part 6 of Article 88 of the RF Criminal Code as of March 9, 2001 eliminated reinforced regime juvenile correctional facilities, in which juvenile criminals who had previously served their sentences were kept. A.N. Kimachev considers such abolition as hasty. The author proposes to keep dangerous criminals in such institutions [3, pp. 42-43]. The State, in turn, encourages more active educational work to achieve gradual decrease in the number of convicts. These changes are triggered by the need to reduce the impact of prison subculture on convicts' social rehabilitation. Many foreign experts emphasize that juvenile offenders should not be deprived of freedom [11, p. 111; 17, p. 215].

\section{Prisons}

As of February 1, 2021, 1,055 convicts and 193 convicts who were left to perform maintenance work served their sentences in 8 prisons.

A certain period of punishment is served in prisons, after which a convicted person is transferred to a correctional colony, the type of which is also determined by the court. The nature of temporary stay in prisons is determined by special (prison) conditions (regimes) in comparison with other colonies. The exception is strict conditions in special regime juvenile correctional facilities, which in fact have strict legal restrictions. In accordance with Part 1 of Article 77 of the PEC of the Russian Federation, in exceptional cases, convicted persons who have not previously served imprisonment, who are to serve their sentence in general regime juvenile correctional facilities, with their consent, may be left in prison to perform maintenance work.

Prison performs the tasks of cell isolation of the most dangerous convicts, as well as limiting the negative influence of regime violators, which is most consistent with the convict classification goals, set in the Nelson Mandela Rules.

Prisons keep persistent violators of the juvenile correctional colony regime from among men for serious and especially serious crimes for a period of more than five years, as well as for particularly dangerous recidivism of crimes, for which the court has imposed part of the punishment in prison. For convicts serving a certain part of the sentence in prison is an assessment of their social danger and is expressed in a criminal classification. For persistent regime violators, transfer to prison acts as a preventive measure of illegal behavior.

The importance of measures aimed at preventing convicts' illegal behavior is acknowledged in all world countries. So, in 2017, American congressmen submitted for consideration a bill, stipulating that a prison bureau is obliged to assess crime commitment risks and, based on the data obtained, differentiate the conditions of serving a sentence [15].

To date, this type of correctional institutions is maximally independent, having no subtypes; however, it is presented in the structure of other types of correctional institutions it terms of isolated sites functioning as prison at the correctional colony. It is important to note that the number of persons serving sentences in prisons and single cells is going down annually. In 2015, the number of people serving a criminal sentence in prison amounted to 1,528 , and those in single cells $-2,000$ people. As of January 1, 2021, there were 1,248 convicts in prisons, and 1,274 - in single cells.

Despite this dynamics, the potential of prisontype facilities in the system and structure of corrective institutions is significant both for functioning of the current corrective institutions system (isolation of persistent violators, when necessary) and elaboration of preventive initiatives.

Convicted former employees of courts and law enforcement agencies, despite the requirement of Part 3 of Article 80 of the Panel Enforcement Code of the Russian Federation, serve their sentences in prison on a general basis, but in isolation from other categories of convicts. It ensures their safety, but contradicts requirements of the law.

\section{Medical correctional facilities}

Medical correctional facilities represent a complex system consisting of their independent sub-types. Few employees of correctional institutions can identify distinctive characteristics of a special tuberculosis hospital, a medical preventive care facility and a medical correctional facility, in which patients with an open form of tuberculosis undergo outpatient treatment.

Subordinate regulatory legal acts define a rather complex system of such institutions, which contains nine sections and includes otolaryngological, ophthalmological, dental de- 
partments of hospitals; psychiatric hospitals; tuberculosis hospitals, etc. [5].

In general information about institutions and the number of suspected offenders [6], classification of these institutions is more modest. It consists of tuberculosis treatment correctional institutions; medical correctional institutions for drug addicts; hospitals. The website of the Federal Penitentiary Service of Russia reveals the following facilities: tuberculosis treatment correctional institutions, hospitals, tuberculosis hospitals, and special psychiatric hospitals.

A.P. Skiba notes that most hospitals are not independent institutions and operate within correctional camps. In his opinion, interregional hospitals have an independent status [9, p. 35].

In our opinion, today it is possible to classify the institutions under consideration into five independent corrective institutions: medical correctional facilities for male convicts with tuberculosis; medical correctional facilities for female convicts with tuberculosis; medical correctional facilities for male drug addicts; medical correctional facilities for female drug addicts; medical treatment and prevention care facilities (hospitals).

\section{Pre-trial detention centers}

Pre-trial detention centers perform the functions of correctional institutions in relation to convicts left for economic maintenance. As of January 1,2021 , there were 5,790 such convicts.

Such convicts are held in the pre-trial detention facility based on the decision of the institution head. According to some scientists, such a procedure contradicts Part 4 of Article 58 of the Criminal Code of the Russian Federation, stipulating that it is the court that renders a decision to change the type of correctional institution [4, p. 182]. According to V.G. Churakov, to solve this problem, it is reasonable to elaborate a transitional stage aimed at complete elimination of the punishment execution mechanism in pre-trial detention facilities [13, p. 77-78].

In our opinion, it is not worth abandoning this practice. It promotes correctional rehabilitation of offenders. At the moment a pre-trial detention center actually acts as a distribution center for suspects. For a certain period, often a long one, they are monitored by the administration and subsequently, in case of meeting the legislative requirements and requirements of the administration, after their conviction they remain in this institution.

Considering the current system of corrective institutions, we should note that Federal Law No.
142-FZ as of July 6, 2007 amended Article 73 of the PEC of the Russian Federation, eliminating the need to transfer convicted foreign citizens and stateless persons to serve their sentences at the location of relevant correctional institutions. Today the specified category of convicts serves their sentences on general terms. The situation when foreign citizens served a sentence in a separate institution separately from Russian convicted citizens looked as strange, as if foreign citizens of different states were kept separately from each other, or Russian citizens of different nationalities were held separately from each other.

It is important to note that, despite the changes in the legislation in 2007, convicted foreign citizens from non-CIS countries continued to endure punishment in the correctional camp number 22 of the Federal Penitentiary Service of Russia in the Republic of Mordovia. Only in 2020 this colony was liquidated.

Prospects for correctional system development

The current system of correctional institutions is unreasonably numerous, which affects possibilities of their interchangeability. The system is constantly under the influence of the state criminal policy and the practice of departmental regulation of panel enforcement relations. The legislator is trying to optimize this system by reducing sub-types of institutions for minors, women, and foreigners, while the practice creates new sub-types for offenders for the first time sentenced to imprisonment and for those previously served a sentence of imprisonment.

Crime is changing, and researchers are proving new assumptions on creating additional types of correctional institutions with regard to a certain category of convicts or their separate keeping. Danger of convicts is mainly determined by the crime committed, and for this reason, the category of a committed crime is the basis for the proposed differentiation.

The current crime rate stresses the necessity to improve a preventive measures system in the current system of correctional institutions (with the creation of its new types being a possible option). The crime rate of convicts held in government institutions amounted to 2.63, per thousand people at the end of 2020, whereas in 2010 it was 1.34. There had been an almost twofold increase over the past ten years.

V.N. Chornyi, sharing V.I. Seliverstov's point of view, notes that it is advisable to change approaches to organizing the execution of pun- 
ishment in the form of imprisonment in relation to those convicted of official and economic crimes. The authors believe that the mentioned categories of offenders should be kept in separate correctional institutions. This measure, in their opinion, will not contradict the general principles of deprivation of liberty established by law for all categories of convicts [8; 12, pp. 74-79].

At the same time, V.N. Chornyi provides interesting statistical data, according to which $12 \%$ of crimes are committed by persons serving a sentence or having an outstanding sentence to imprisonment. What is more, $85.7 \%$ of convicts have committed a crime while serving their sentence in correctional institutions, mostly these are acts stipulated by articles 175, 186, 187 of the Criminal Code of the Russian Federation. At the time of conviction, 716 perpetrators of crimes had unexpunged or unexpired convictions: 51 people for particularly serious crimes, 254 for serious crimes, 233 for medium-gravity crimes, and178 for little-gravity crimes. Of this group 244 people were recidivists, 47 - dangerous recidivists, 7 - especially dangerous recidivists [12, pp. 77-78]. Besides, there are situations when a person, being released after serving a sentence for murder, committed an economic crime.

Based on the data provided, the author actually proposes formation of 6 additional correctional institutions sub-types for the specified category of convicts to serve their imprisonment sentence: correctional colonies of general regime for first-time convicts and those who have previously served their sentences; correctional colonies of strict regime for first-time convicts and those who have previously served their sentences; correctional colonies of special regime for first-time convicts and those who have previously served their sentences.

In our opinion, no changes to the legislation are required. It seems possible, that in case of an economic crime committed for the first time to send a convict to separate correctional camps for former employees of courts and law enforcement agencies.

In the future, according to experts, the expansion of the correctional institution system is possible by establishing separate institutions for those convicted of terrorism and extremism-related crimes. In 2016, the Ministry of Internal Affairs of Russia advanced the initiative to set up such colonies. This possibility was discussed at various levels, including in the Security Council of the Russian Federation.
According to A.Ya. Grishko, growing terrorism and extremism-related crimes and possible negative impact of the offenders convicted of such crimes on other convicts necessitate the execution of punishment against this category of convicts in prison or correctional colony of special regime in cell conditions. This ensures complete isolation of extremists and terrorists from other convicts [1, p. 90].

V.I. Seliverstov notes that time dictates the need to take such measures. In his opinion, this category should serve their sentences not in separate colonies, but in prisons, in which cells are provided, which will allow more individualized accommodation of various categories of prisoners [7, p. 139]. To achieve this goal, it is necessary to revise the Criminal Code of the Russian Federation. The proposals should be aimed at changing sanctions for crimes of terrorist and extremist orientation; today panel enforcement relations in terms of differentiation of those sentenced to imprisonment depend on criminal legislation, despite the independent subject of legal regulation. But do we need these changes, if there are no problems with maintenance of this category of convicts today?

Experts note that the concentration of this category of convicts in one place, even in cell conditions, will worsen the possibilities of carrying out measures for operational work. In conditions when the one convicted of terrorism is in the dormitory of a correctional colony, it is easier to organize preventive measures.

As of January 1, 2021, 1,979 convicts served sentences in correctional institutions for terrorism-related crimes: 484 in correctional colonies of general regime, 1,002 - of strict regime, 72 of special regime (47 of which were sentenced to life), 10 - in panel settlements. In correctional colonies, 305 convicts served sentences for crimes of extremist orientation, of which: 79 in colonies of general regime, 191 - of strict regime, 22 - of special regime (20 of which were sentenced to life), 13 - in panel settlements.

It should be noted that in case of such inmates' misbehavior in correctional institutions, under the current legislation they are transferred to prisons. It was noted above that the number of convicts held in prisons and cells is declining and the occupancy of these institutions is a far cry from the limit. Hence, it can be stated that there are no obstacles to crime prevention in relation to this category of convicts and there is no need to accommodate them in separate correctional institutions. 


\section{Conclusion}

The RF Government Decree addresses some issues that are directly dependent on the correctional institution system functioning. The Federal target program "Development of the Panel Enforcement System (2017-2025)" notes that the current system of correctional institutions and their territorial location fail to implement the legislatively fixed principle of serving sentences in the territory of a RF subject, where convicts lived or were convicted.

This requirement does not really apply to the principles of panel enforcement legislation and any principles at all. Moreover, even scientists' assumptions seem to be quite controversial due to a sufficiently wide system of correctional institutions, which cannot be built in each subject because of small population of individual regions and unreasonably large government expenditure on constructing such facilities. The Tomsk Oblast territory, for instance, is approximately $20 \%$ larger than the territory of Great Britain, and the population of the region is 62 times smaller. There are more than twenty types of correctional institutions with their various sub-types provided by legislation and practice. It seems necessary to give more profound consideration to the issues of expanding the system of institutions and declaring the possibility of placing all types in one RF subject.

\section{Discussion}

Summing up, we can draw the following conclusions:

1. The current system of correctional institutions is significantly broader than the boundaries defined by criminal and panel enforcement legislation. The ambivalently interpreted provisions of Article 80 of the RF Panel Enforcement Code give the opportunity to expand the system of correctional institutions at the departmental level, thus reducing the possibility for a convicted person to serve his/her sentence in the region of residence, but, at the same time, promoting achievement of panel enforcement legislation goals.

2. According to our calculations, today the execution of a custodial sentence is organized with the help of 25 different institutions (including for those sentenced to life imprisonment): 7 types (sub-types) of correctional camps of general regime, 3 types (sub-types) of correctional colonies of strict regime, 3 types (sub-types) of correctional colonies of special regime, 3 types of panel settlements, 2 types of juvenile correctional facilities, 1 type of prison, 5 types (sub- types) of medical correctional facilities, 1 type of pre-trial detention center.

Departmental regulation should not expand the legislatively established system of correctional institutions. It seems reasonable to maintain 3 (instead of 7) correctional colonies of general regime: for convicted men, for convicted women, for convicted men from among former employees of courts and law enforcement agencies; 2 types (instead of 3) correctional colonies of strict regime: for convicted men; for convicted men from among former employees of courts and law enforcement agencies.

Constructing new colonies, which meet the requirements of separate accommodation of convicts, helps eliminate functioning of correctional colonies for women and minors.

3. The legislator makes efforts to reduce the number of types by eliminating certain types of correctional institutions for minors, women, and foreigners, while the practice creates new sub-types for first-time convicts sentenced to imprisonment and those who previously served a sentence of imprisonment. Due to this circumstance, Article 80 of the Panel Enforcement Code of the Russian Federation needs substantial revision to exclude opportunities for changing the number of types of correctional institutions not to contradict the law.

4. Nowadays, the state criminal policy, reflected in the legislation, practice of punishment execution in the form of imprisonment and scientists' stance differ in matters of the correctional institution system. Since the adoption of the panel enforcement legislation, there have been the following changes: juvenile correctional facilities of reinforced regime are liquidated; the possibility for convicted women to serve sentences in correctional colonies of strict, special regime and prisons is excluded; convicted foreign citizens are sentenced to imprisonment on general grounds. The possibility of creating isolated sites of certain institutions on the territory of other correctional institutions is enshrined in the law. At the same time, according to the order of the Director of the Federal Penitentiary Service of Russia, issued in 2010, sub-types of correctional colonies of general and strict regimes are created for those convicted for the first time to imprisonment and those who have previously served a sentence of imprisonment. Some representatives of the scientific community, in turn, express their views on the need to create additional sub-types of colonies.

5. The mechanism of performing the functions of correctional institutions in relation to 
convicts held to perform maintenance work in pre-trial detention facilities and prisons seems to be more consistent with the penitentiary system mechanism in Western countries. Candidates for serving their sentence in detention centers are under close observation during the period when they are not convicted, which makes it possible to study these individuals in more detail. This mechanism is similar to the operation of distribution centers of some European penitentiary systems.

\section{REFERENCES}

1. Grishko A.Ya. Personal characteristics of convicts for terrorism and extremist activities: the feasibility of taking into account in the execution of sentences of imprisonment. Penitentsiarnoe pravo: yuridicheskaya teoriya $i$ pravoprimenitel'naya praktika=Penal Law: Legal Theory and Law Enforcement Practices, 2019, vol. 20, no. 2, pp.87-93. (In Russ.).

2. Ivanov V.D. Correctional centers or panel settlements? Ugolovno-ispolnitel'naya sistema: pravo, ekonomika, upravlenie=Criminal-Executory System: Law, Economy, Management, 2005, no 1, p. 24. (In Russ.).

3. Kimachev A.N. On the issue of staying young offenders sentences to imprisonment in education colonies coming the age of majority. Vestnik instituta: prestuplenie, nakazanie, ispravlenie=Institute Bulletin: Crime, Punishment, Correction, 2016, vol. 35, no. 3, pp. 42-43. (In Russ.).

4. Laverycheva S.A. Executing punishment in pre-trial detention facilities. Voprosy rossiiskogo i mezhdunarodnogo prava=Matters of Russian and International Law, 2018, vol. 8, no. 7A, p. 182. (In Russ.).

5. On the approval of the Lists of medical preventive care and medical correctional facilities of the penal system for the provision of medical care to convicts : Order of the Ministry of Justice of the Russian Federation as of August 16, 2006 No. 2 63. Byulleten' Minyusta Rossii=Bulletin of the Ministry of Justice of Russia, 2006, no. 10. (In Russ.).

6. Osnovnye pokazateli deyatel'nosti ugolovno-ispolnitel'noi sistemy. Yan-var'-dekabr' $2017 \mathrm{~g}$. : informatsionnoanaliticheskii sbornik [Key indicators of the activity of the penal enforcement system. January-December 2017 : information and analytical collection]. Tver', 2018.

7. Seliverstov V. I. On penal enforcement measures of responding to terrorism. In: Dolgova A.I. (Ed.). Kriminal'nye realii, reagirovanie na nikh i zakon [Criminal realities, response to them and law]. Moscow : Ros. kriminol. assots., 2018. P. 139. (In Russ.).

8. Seliverstov V.I. The serving imprisonment convicted of economic and official crimes with the use of their intellectual and creative potential: new research project. Ugolovno-ispolnitel'noe pravo=Penal Law, 2017, vol. 12, no. 1, p. 36. (In Russ.). 9. Skiba A.P. Ispolnenie nakazaniya v lechebno-profilakticheskikh uchrezhdeniyakh : dissertatsiya na soiskanie uchenoi stepeni. kandidata yuridicheskikh nauk [Execution of punishment in medical preventive care facilities: Candidate of Sciences (Law) dissertation abstract]. Rostov-on-Don, 2003. 35 p.

10. Utkin V.A., Kiselev M.V., Savushkin S.M. "Hybrid" and "multi-mode" penitentiary institutions: advantages and risks. Vestnik Tomskogo gosudarstvennogo universiteta. Pravo=Tomsk State University Journal of Law, 2018, no. 29, p. 103. (In Russ.).

11. Fefelov V.A. Sotsial'no-pravovye osnovy ugolovno-ispolnitel'noi tsi-vilizatsii uchrezhdenii, ispolnyayushchikh ugolovnoe nakazanie $v$ vide lisheniya svobody [Socio-legal foundations of the penal enforcement civilization of institutions executing criminal punishment in the form of deprivation of liberty]. Ryazan', 1992. P. 53.

12. Chornyi V.N. Peculiarities of imprisonment execution in respect of persons who have committed crimes in economy. Vestnik Samarskogo yuridicheskogo instituta=Bulletin of Samara Law Institute, 2018, no 4 (30), pp. 74-79. (In Russ.).

13. Churakov V.G. Some organizational and legal problems of serving sentences of certain categories of convicts. Vestnik Voronezhskogo instituta FSIN Rossii=Vestnik of Voronezh Institute of the Russian Federal Penitentiary Service, 2015, no. 2, pp. 77-78. (In Russ.).

14. Bard E., Knight M., Plugge E. Perinatal health care services for imprisoned pregnant women and associated outcomes: a systematic review. BMC Pregnancy Childbirth, 2016, no. 1, vol. 16, p. 285.

15. Kirchner L. Should we rank prisoners by «risk score»? Pacific Standard, 2017. Available at: https://psmag.com/news/ should-we-rank-prisoners-by-risk-score (accessed May 1, 2021).

16. Lasosik Z., Platek M., Rzeplinska I. Abolitionism in History: on Another Way of Thinking. Warsaw: Institute of Social Prevention and Resocialization, 1991. $200 \mathrm{p}$.

17. Pepinsky H., Quinney R. Criminology as Peacemaking. Bloomington: Indiana Univ. Press, 1991. 339 p.

\section{INFORMATION ABOUT THE AUTHOR}

SERGEI M. SAVUSHKIN - Candidate of Sciences (Law), Associate Professor, Deputy Head for Academic and Scientific Work of the Tomsk Institute of Advanced Training of Employees of the Federal Penitentiary Service of Russia, Tomsk, Russian Federation, ORCID: 0000-0002-5744-8178, e-mail: savusertom@rambler.ru 